\title{
Pengembangan Prototype Sistem E-Commerce pada Ajun Elektronik dengan Metode FAST
}

\author{
Sarwindah $^{[1]^{*}}$, Elly Yanuarti ${ }^{[2]}$ \\ Fakultas Ekonomi Bisnis $^{[1]}$, Fakultas Teknologi Informasi ${ }^{[2]}$ \\ Prodi Bisnis Digital ${ }^{[1]}$, Prodi Sistem Informasi ${ }^{[2]}$ \\ ISB Atma Luhur,Pangkalpinang, Bangka Belitung \\ indah_syifa@atmaluhur.ac.id ${ }^{[1]}$, elly@atmaluhur.ac.id ${ }^{[2]}$
}

\begin{abstract}
While the development of information technology is very influential for the progress of a business, promoting a business that is owned, then one of them by using an ecommerce website. $E$ commerce is a trading activity carried out online through a website. Problems in electronic adjunct stores Stores still use a conventional system where if a buyer wants to buy the desired item, the buyer must come directly to the store and this condition makes marketing and sales hampered by distance and time. In addition, the promotion at Arjun Electronics Store has not been fully implemented properly because it is only done by directly informing buyers who come to the shop. the purpose of this research is to produce a system that can provide ease of introducing products in the electronic adjuncts and sell all electronic products for household needs. With e-commerce site that is able to provide information about goods to customers quickly through internet network technology. Where asthe FAST method is a fairly flexible framework for various types of projects and strategies. System development with the FAST method is carried out sequentially which includes the stages of scope definition, problem analysis, needs analysis, logical design, decision analysis, physical design and integration, construction and testing, insralation and delivery, The results of this study in the form of website-based e-commerce optimization. With this website, stores can expand marketing, consumers become easier to get information about goods without having to come to the Electronic Adjunct Store and with the (ecommerce), the store can facilitate the conventional transaction process that has been conventional to be modern and can certainly make it easier to create sales reports that were previously still manual.
\end{abstract}

Keywords-Development; E-commerce; FAST

Abstrak - Semangkin berkembangnya teknologi informasi sangatlah berpengaruh untuk kemajuan suatu usaha, salah satunya adalah usahan jual beli, dimana berbagai macam cara dilakukan untuk mempromosikan usaha yang dimiliki, maka salah satunya dengan menggunakan website ecommerce. Ecommerce adalah suatu kegiatan jual beli yang dilakukan secara online melalui website. Permaslahan pada toko ajun elektronik Toko masih memakai sistem konvensional yang mana bila ada pembeli yang ingin membeli barang yang diinginkan, pembeli harus datang langsung ke toko dan kondisi ini membuat pemasaran dan penjualan terhambat oleh jarak dan waktu. Selain itu, promosi pada Toko Arjun elektronik belum sepenuhnya dilaksanakan dengan baik karena hanya dilakukan dengan menginformasikan langsung kepada pembeli yang datang ke toko. Tujuan penelitian menghasilkan sistem yang dapat memberikan kemudahan mengenalkan produk di Ajun elektronik dan menjual semua produk elektronik kebutuhan rumah tangga, Dengan adanya wevsite e-commerce yang mampu memberikan informasi mengenai barang kepada pelanggan dengan cepat melalui teknologi jaringan internet. Sedangkan metode FAST adalah sebuah kerangka kerja yangcukup fleksibel untuk berbagai jenis proyek dan strategi. Pengembangan sistem dengan metode FAST dilakukan secara berurutan yaitu meliputi tahapan definisi lingkup, analisis masalah, analisis kebutuhan, desain logis, analisis keputusan, desain fisik dan integrasi, kontruksi dan pengujian, insralasi dan pengiriman Hasil penelitian ini berupa optimasi e-commerce berbasis website, Dengan adanya website ini maka toko dapat memperluas pemasaran, Konsumen menjadi lebih mudah mendapatkan informasitentang barang tanpa harus datang ke Toko Ajun Elektronik dan dengan adanya sistem penjualan online (ecommerce) maka toko dapat memudahkan proses transaksi yang selama ini sifatkan konvensional menjadi modern dan tentunya dapat mempermudah dalam membuat laporan penjualan yang sebelumnya masih bersifat manual.

Kata Kunci-Pengembangan; E-commerce; FAST

\section{PENDAHULUAN}

Toko Ajun elektronik merupakan toko yang menjual elektronik kebutuhan rumah tangga, toko ini berada di Bangka Barat dan Toko ini masih memakai sistem konvensional yaitu kalau ada pembeli yang ingin membeli barang yang diinginkan, pembeli harus datang membeli dan mendatangi toko ini, kondisi ini membuat pemasaran dan penjualan terambat oleh jarak dan waktu. Selain itu, promosi pada Toko Arjun elektronik belum sepenuhnya dilaksanakan dengan baik karena hanya dilakukan dengan menginformasikan langsung kepada pembeli yang datang ke toko.Sehingga menyebabkan konsumen yang berada ditempat yang jauh kesulitan dalam informasi stok dan informasi mengenai barang yang disediakan. Toko Ajun elektronik dalam pembuatan laporan rekapitulasi (ringkasan) penjualan juga masih menggunakan cara manual dan belum terperinci dengan baik. Untuk memecahkan masalah ini maka, diperlukan suatu sistem perdagangan online atau lebih dikenal dengan istilah $E$ - 
commerce.

E-commerce didefinisikan sebagai aktivitas pengguna teknologi informasi dan komunikasi pengolahan digital dalam melakukan transaksi bisnis untuk menciptakan, mengubah, dan mendefinisikan kembali hubungan anatara penjual dan pembeli. Dan dapat diartikan juga sebagai aktivitas transaksi jual beli barang, servis atau transmisi dana atau data dengan menggunakan elektronik yang terhubung dengan internet. Konsumen dapat membeli barang tanpa harus datang langsung ke toko karena dengan E-commerce konsumen dapat melakukan pembelian kapan saja dan dimana saja

Beberapa penelitiansebelumnyapernahmelakukan penilitian pengembangan Prototype tentang Sistem informasi yang dibangun adalah sistem informasi untuk penjualan garam secara online menggunakan metode OOAD dengan bahasa pemrograman PHP dan database Mysql. [1], Penelitian tentang Analisis Bisnis E-Commerce Pada Mahasiswa Universitas Islam Negeri Alauddin Makassar, berdasarkan hasil analisis data dan pembahasan dapat disimpulkan bahwa transaksi onlinesebenarnya cukup efesien dari segi waktu dan

effort, namun belum kuatnya regulasi di dalamnegeri sehingga membuat orang eggan, karenatidak adanya perlindungan hukum terhadap terjadinya fraud (penyalahgunaan informasifinansial). Selain itu kasus kriminalitas transaksionline yang dipublish cukup dahsyat dankurangnya publishing mengenai benefit(manfaat) transaksi online sehingga membuatsebagian orang menilai bisnis ini lumayan/cukuplumayan dan bahkan ada yang menilai tidak

baik. [2]. Pada penelitian Implementasi E-Commerce Sebagai Media Penjualan Online hasil penelitian ini diharapkan dapat membantu toko Pastbrik untuk mendapatkan hasil yang lebih maksimal serta dapat bersaing dengan toko yang sejenis..[3]. Penelitian Penerapan Model Customer Relationship Managementpada Metodologi Fast Hasil penelitian menunjukkan bahwa penerapan model CRM pada metodologi FAST untuk mengembangkan web portal akademik berpengaruh secara signifikan terhadap tingkat kepuasan baik secara bersama-sama maupun secara individual[4]. Penelitian Metode Pengembangan FAST (Freamwork For Application Of Systems Technology) Luaran yang dihasillan pada penelitian ini adalah sistem yang dapat memudahkanproses bisnisdalam perusahan,[5]. Penelitian Pemanfaatan Aplikasi Dekstop Dalam Proses Sistem Pengiriman Furnicture Pada A \& N Interior, Suatu sistem dikatakan baik apabila akan memudahkan semua proses, salah satunya, dengan Aplikasi berbasis dekstop sistem komputerisasi yang memberikan kemudahan dalam melakukan suatu kegiatan, terutama bagi CV. A \& $\mathrm{N}$ furnicture Interior.[6]. Penelitian Sistem Penjualan Elektronik Batik Pacitan Berbasis Website, Penelitian tentang batik di Kabupaten Pacitan menghasilkan website yang digunakan sebagai media promosi batik Pacitan. Sebagai media $e$ commerce, batikpacitan.com dapat digunakan untuk melakukan transaksi jual beli secara online.[7]. Penelitian ECommerce In Indonesia [8]. Penelitian Sistem Informasi
Eksekutif Sebaran Penjualan Kendaraan Bermotor Roda 2 Di Kalimantan Timur Berbasis Web, Solusi yang ditawarkan sistem ini tidak hanya dalam gambaran penulis, melainkan dari kebutuhan, kinerja dan waktu yang ada di lingkungan teknologi yang selalu berkembang setiap saat maka terwujudlah sistem informasi. [9]. Penelitian E-Commerce Penjualan Berbasis Metode Ooad Dengan adanya e-commerce untuk penjualan berbasis web maka bisa membantu administrasi penjualan perusahaan dan juga mempermudah customer dalam melakukan penjualan.dan penggunaan ecommerce ini juga bisa digunakan sebagai promosi produk yang ada diperusahaan. [10]. Penelitian Sistem Pendaftaran Siswa Baru Pada SMP N 1 Kelapa Berbasis Web Menggunakan Model UML, Hasil dari penelitian ini menunjukkan bahwa sistem ini mampu mengelola proses penerimaan siswa baru di SMP N 1 Kelapa menggunakan PHP dan MYSQL [11]. Penelitian Implementasi E-Commerce Sebagai Media Penjualan Online Hasil penelitian menggunakan implementasi e-commerce dengan menggunakan software opencart pada toko Pastbrik Malang akan dapat membantu mengurangi biaya yang dikeluarkan serta dapat menyampaikan informasi secara detail dan cepat mengenai produk kepada pelanggan, Berdasarkan hasil penelitian ini diharapkan dapat membantu toko Pastbrik untuk mendapatkan hasil yang lebih maksimal serta dapat bersaing dengan toko yang sejenis.[12]. Penelitian Pengaruh ECommerce Terhadap Keputusan Pembelian Pada Belanja Online Shopee Pengujian hipotesis menunjukkan bahwa adanya pengaruh e-commerce terhadap keputusan pembelian pada belanja online shopee. Nilai persamaan $\mathrm{Y}=8.394+$ $0.273 \mathrm{X} 1+0.036 \mathrm{X} 2+0.193 \mathrm{X} 3+$ e. Koefisien determinas $\left(\mathrm{R}^{2}\right)$ interface (X1) content (X2) dan technical (X3) menunjukkan nilai sebesar $16,5 \%$ untuk keputusan pembelian, sedangkan sisanya dipengaruhi oleh faktor lain yang tidak diteliti. [13].Penelitian Pemanfaatan Web E-Commerce Untuk Meningkatkan Strategi Pemasaran, Sasaran utama pemanfaatan Teknolohi E-commerce ini adalah UMKM Industri Kerajinan Kulit di Magetan. Dari hasil uji coba dan evaluasi yang dilakukan pada Koperasi Mahasiswa STT Dharma Iswara Madiun, menunjukkan bahwa dengan memanfaatkan Teknologi E-commerce memenuhi strategi pemasaran produk yang dapat berdampak pada peningkatan pendapatan. [14], Penelitian Perancangan Sistem E-Commerce Untuk Memperluas Pasar Produk Oleh-Oleh Khas Pontianak, Hasil perancangan sistem E-Commerce dapat menampilkan semua informasi mengenai produk oleh-oleh khas Kota Pontianak. Sistem penjualan tidak lagi hanya fokus kepada masyarakat setempat saja, yang semakin hari semakin banyak pesaingnya. [15], Penelitian Perancangan system informasi penjualan berbasis E-Commercestudi Kasus Toko Kun Jakarta, tujuan dari penelitian adalah memberi solusi pemecahan masalah-masalah yang ada dengan merancang sebuah sistem informasi penjualan berbasis ecommerce. Hasil dan kesimpulan dari penelitian ini adalah website penjualan

berbasis ecommerce dapat dijadikan sebagai media promosi, mempermudah proses penjualan yang dilakukan secara online, serta dapat mempermudah dalam pengolahan data dan 
pencetakan laporan yang tidak lagi memerlukan pencatatan dalam bentuk arsip. [16].

Dengan adanya website ini maka toko dapat memperluas pemasaran, Konsumen menjadi lebih mudah mendapatkan informasitentang barang tanpa harus datang ke Toko Ajun Elektronik dan dengan adanya sistem penjualan online ( $e$ commerce) maka toko dapat memudahkan proses transaksi yang selama ini sifatkan konvensional menjadi modern dengan terjadinya transaksi online.

\section{METODOLOGI PENELITIAN}

Metodologi penelitian yang dipergunakan dalam penelitian ini adalah menggunakan metodologi FAST (Framework for the Application of Systems Thinking).

Pengembangan sistem informasi ini dilakukan dengan menggunakan metodologi proses pengembangan sistem yang bernama FAST (Framework for the Application of System Thinking). Metode FAST ini memiliki beberapa keunggulan diantaranya : (1) Persyaratan bisnis dan desain sistem lebih mudah divalidasi karena adanya model-model sistem; (2) Spesifikasi kebutuhan dianalisis lebih menyeluruh dan didokumentasikan dengan baik; (3) Spesifikasi desain cenderung stabil, solid karena disesuaikan dengan kebutuhan dan fleksibel karena berbasis model; (4) Sistem dapat dikonstruksikan dengan lebih tepat saat pertama kali dibangun dari spesifikasi berbasis model yang menyeluruh dan jelas. Menurut Whitten terdapat 8 (delapan) tahap pengembangan dalam metode FAST, dimana tahapan ini akan dikerjakan secara berurutan sehingga menghasilkan suatu pemahaman yang mendalam mengenai masalah pada sistem yang berjalan serta rancangan sistem yang diusulkan. Adapun fase-fase tersebut adalah sebagai berikut :

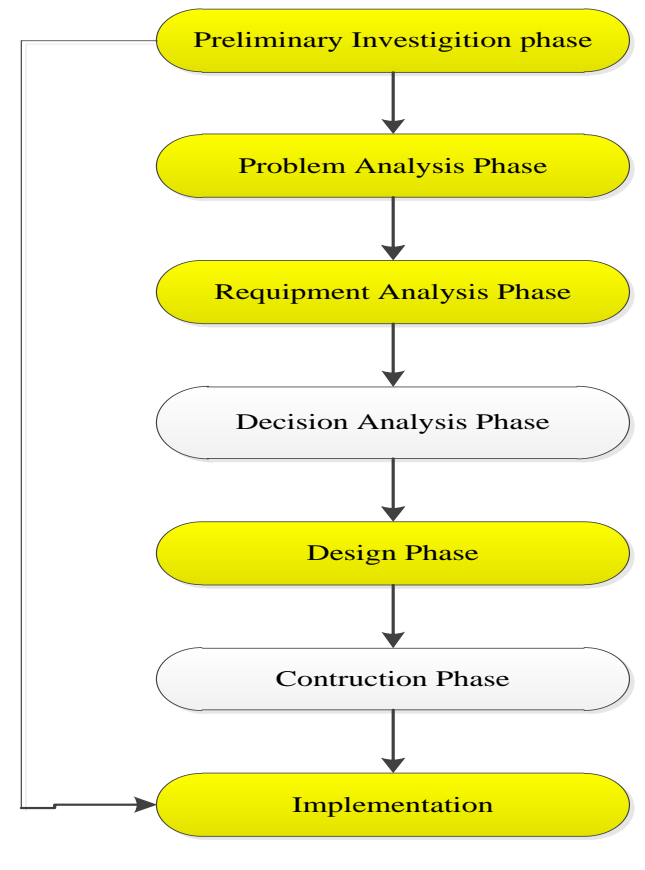

Gambar 1. Metode FAST
Gambar 1 menjelaskan tahapan -tahapan yang digunakan pada penelitian ini dengan memakai Model FAST.

Pengembangan sistem dengan metode FAST dilakukan secara berurutan yakni melalui terhadap investigasi atau survei awal, analisis masalah, analisis kebutuhan, analisis keputusam, pembuatan rancangan mengkontruksi menerapkan system, mengoperasikan dan pemelihraan sistem. Pengembangan ini bersifat daur hidup karena setelah selesai tahapan implementasi dan pemeliharaan maka sistem tersebut akan memberikan umpan balik ke analisis sistem yang telah dirancang, Sehingga tahapan pengembalian diatas terus menerus dilakukan demi penyempurnaan sistem.Berikut akan dijelaskan fase-fase metode penggunaan FAST

\section{A. Phase 1 :Preliminary Investigation Phase}

Tahap ini merupakan tahap awal dari pengembangan sistem.Fase ini berisikan investigstion awal ketika ingin merancang sebuah sistem, seperti wawancar, tinjauan langsung dan memplajari dokumen perusahaan.Hasil investigasi harus mampu menjawab berbagai pertanyaan.

\section{B. Phase 2 : Problem Analysis Phase}

Problem analisi ialah menganalisi masalah-masalah yang terdapat di lapangan. Analisis masalah dapat didifinisikan sebagai penguraiaan dari suatau sistem informasi yang utuh kedalam bagian komponenya, dengan maksud untuk mengidentifikasi dan mengevaluasi permasalahan,kesempatan dan hambatan-hambatanyang terjadi serta kebutuhan yang diharafkan sehingga dapat diusulkan perbaikan dalam tahapan ii dilakukan penelitian terhadap komponen komponen sistem untuk memahami sistem yang ada, sebagai dasar untuk rancangan sistem yang diharafkan dengan cara melakukan wawancara pada pelaku-pelaku sistem.

\section{Phase 3: Requirement Analysis Phase}

Pada tahap ini analisi kebutuhan dialakukan pengumpulan dan analisis data,terutama menyangkut kebutuhan para pengguna sistem, dan menilai kekuatan maupun kelemahan metode kerja yang telah diterapkan selama ini,dalam FAST ada 4 sumber informasi digunakan untuk analisi kebutuhan : Dokumen, Wawancara, dan Observasi.

\section{Phase 5 : Design phase}

Setalah diperoleh proposal sistem yang disetujui maka dapat mulai dilakukan proses desain dan sistem target.Tujuan dari tahap ini adalah untuk men-Tranformasi-kan bussines requirment statment menjadi spesifikasi desain untuk proses contruksi.

\section{E. Phase 6 ; implementation phase}

Construction phase ialah tahapan melaksanakan pengujian pada kompenen sistem secara individual dan sistem secara keseluruhan tujuan dari tahap ini adalah:

1) Membangun dan menguji sistem yang memenuhi business requirment dan spesifiaksi desain. 
2) Meng-implementasi-kan penghubung antara sistem baru dan sistem lama termasuk instalasi dari sofware yang dibeli atau disewa.

Berikut ini metode penelitian yang penulis gunakan untuk mendapatkan data-data yang diperlukan:

1) Observasi

Metode ini dilakukan untuk mendapatkan data mengenai objek yang akan diteliti dengan cara mengamati langsung ke tempat objek penelitian.

2) Wawancara

Wawancara atau tanya jawab langsung kepada pemilik toko yang berkaitan dengan sistem yang sedang diteliti.

3) Dokumentasi (Documentation)

Pengumpulan data dengan cara mempelajari dokumentasi tertulis yang berkaitan dengan sistem informasi pengolahan data.

Alat Bantu Analisa dan Perancangan Sistem menggunakan UML diantaranya :

1) Activity Diagram

Proses bisnis sistem informasi dapat diterangkan pada Activity Diagram untuk memperlihatkan urutan aktifitas proses sebagai berikut :

a) Activity Diagram Pencatatan pelanggan

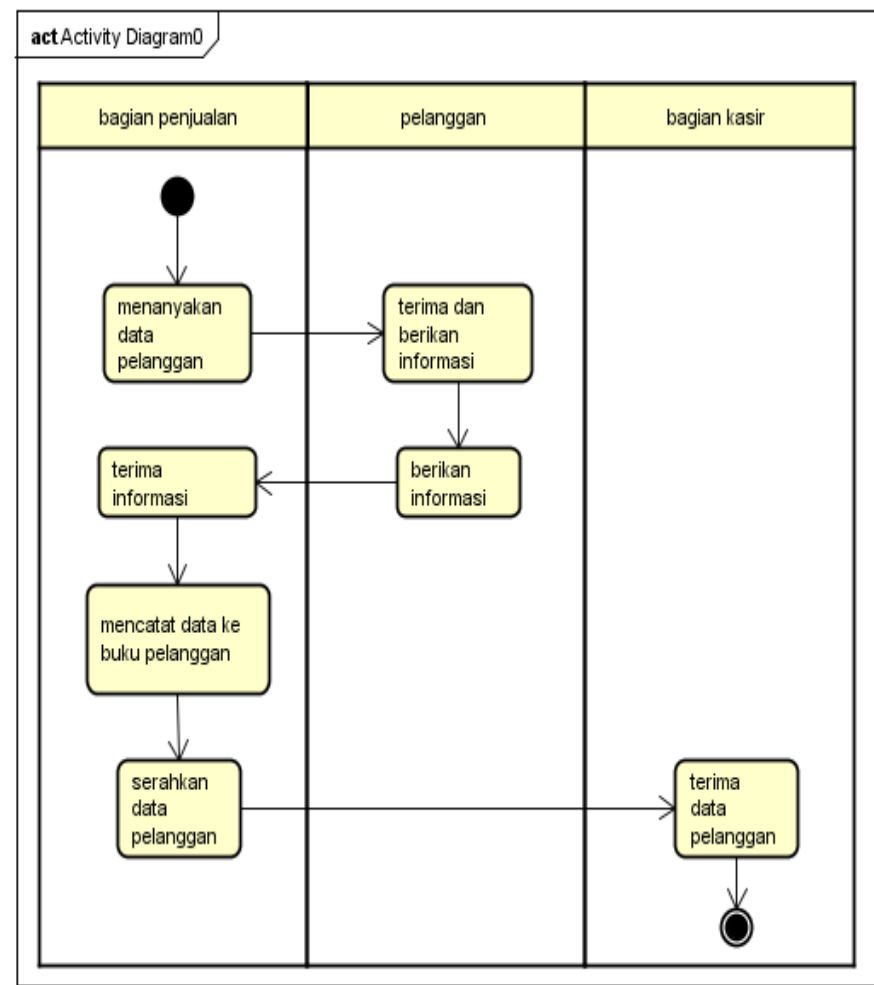

Gambar 2. Activity Diagram Pencatatan Pelanggan

Gambar 2 Proses bisnis Pencatatan data pelanggan, Bagian penjualan menanyakan data kepada pelanggan, pelanggan memberikan data ke bagian penjualan, kemudian bagian penjualan mencatat data pelanggan dan menyerahkan data pelanggan ke bagian kasir.

\section{b) Activity Diagram Pemesanan Barang}

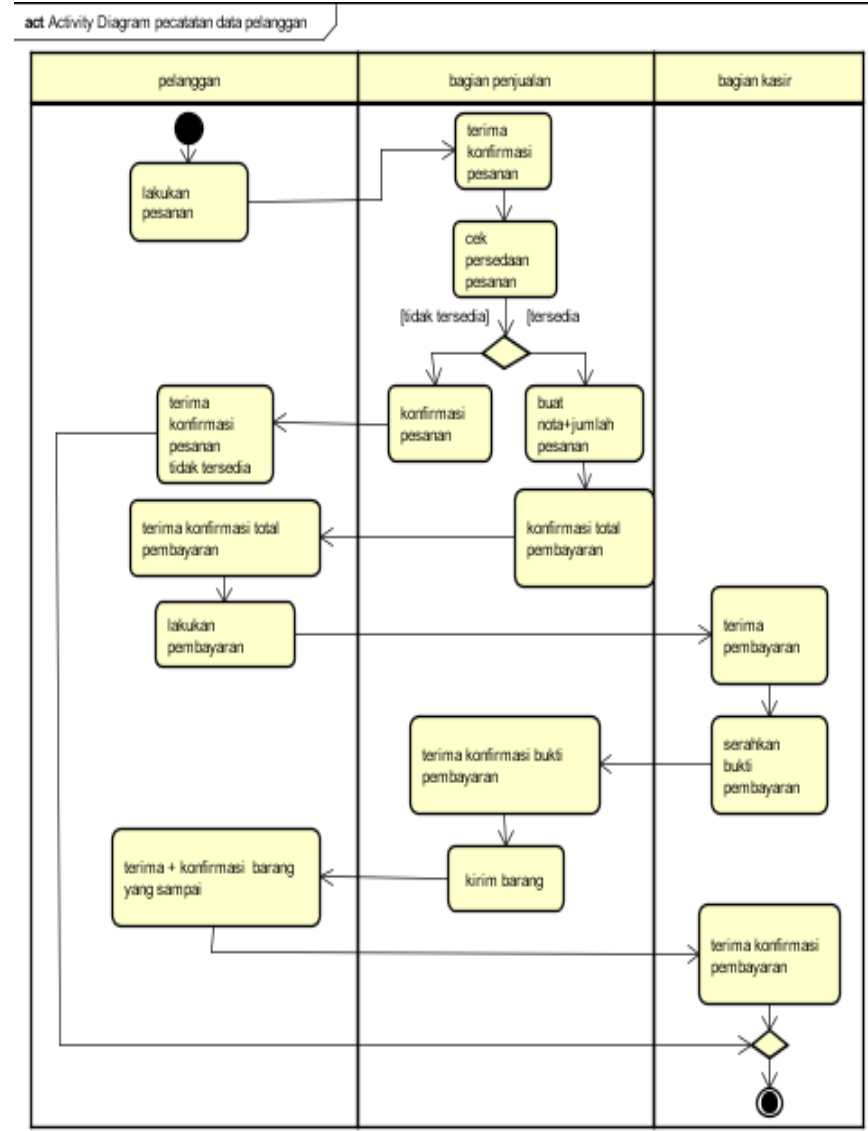

Gambar 3. Activity Diagram Pencatatan Pesanan Barang

Gambar 3 Proses bisnis berjalan Pencatatan Pemesanan Barang Pelanggan dalam melakukan pemesanan barang yang ingin dibeli. Lalu bagian penjualan mengecek persediaan barang yang dipesan oleh pelanggan. Jika persediaan barang tidak tersedia maka, bagian penjualan mengkonfirmasikan bahwa persediaan barang habis. Jika persediaan tersedia, maka bagian penjualan membuat nota pesanan dan mengkonfirmasikan ke pelanggan untuk melakukan pembayaran. Lalu pelanggan menerima konfirmasi pembayaran. Pelanggan melalakukan pembayaran ke bagian kasir. Lalu bagian kasir menerima pembayaran tersebut. Bagian penjualan kirim barang kepada pelanggan setelah itu pelanggan mengkonfirmasikan kepada kasir bahwa pesanan sudah sampai.

c) Activity Diagram Pencatatan Laporan Penjualan 


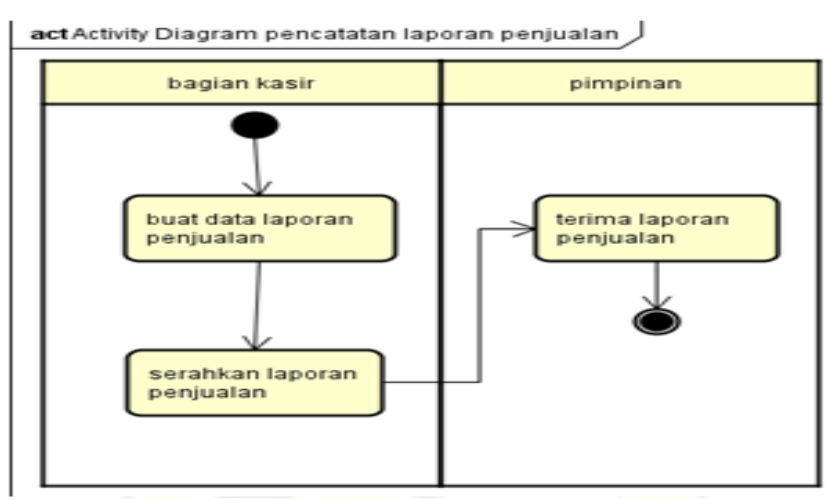

Gambar 4. Activity Diagram Pencatatan Laporan Penjualan

Bagian Kasir membuat data laporan penjualan barang berdasarkan data pemasukan dan pengeluaran. Lalu laporan diserahkan kepada pimpinan.

\section{2) Use Case Diagram}

Use case diagram digunakan untuk menggambarkan kebutuhan sistem dari sudut pandang User, maka dapat digambarkan dengan Use Case Diagram sebagai berikut :

\section{a) Use Case Diagram Admin}

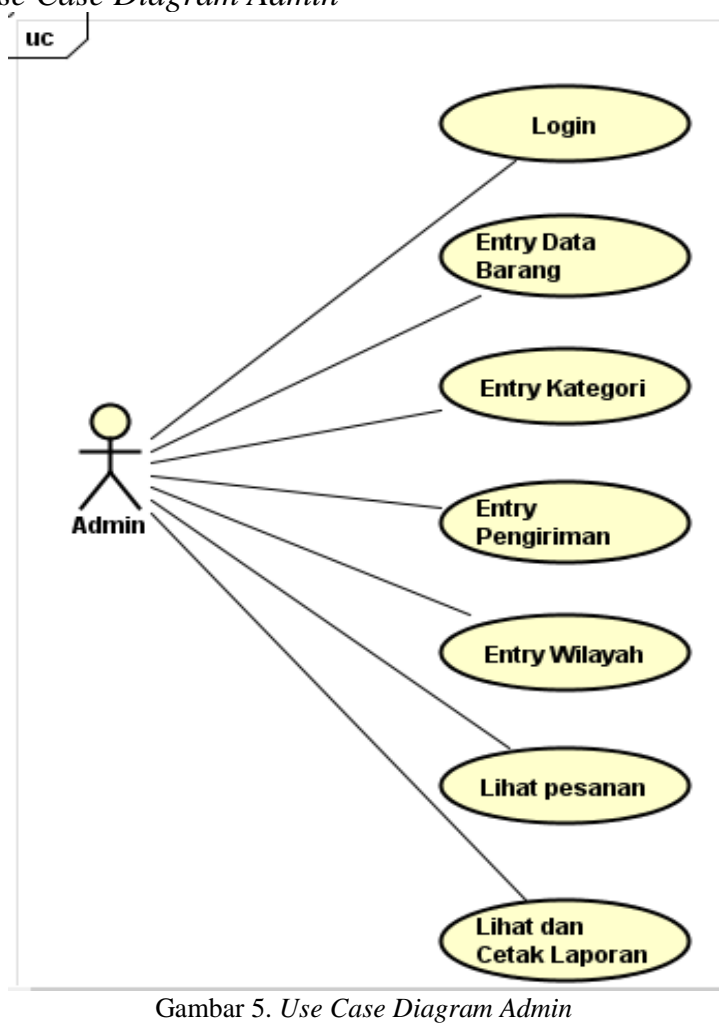

Gambar 5 menunjukkan kebutuhan sistem dari sisi admin.

b) Use Case Diagram Pelanggan

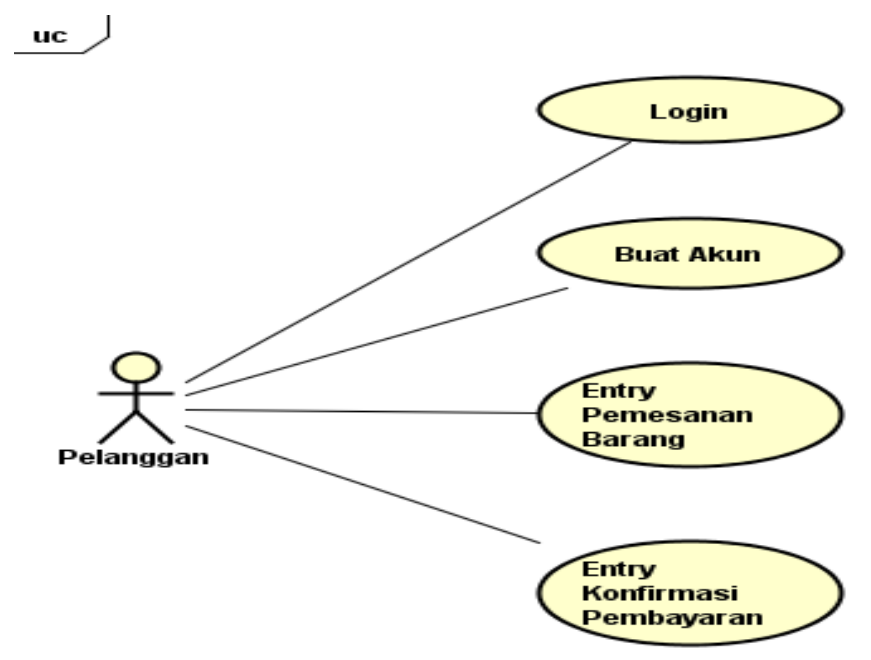

Gambar 6. Use Case Diagram Pelanggan

Gambar 6 menunjukkan kebutuhan sistem dari sisi pelanggan.

\section{3) Class Diagram}

Berdasarkan analisis kebutuhan, berikut ini adalah class diagram yang digunakan untuk menggambarkan sistem dan relasi-relasi di dalamnya.

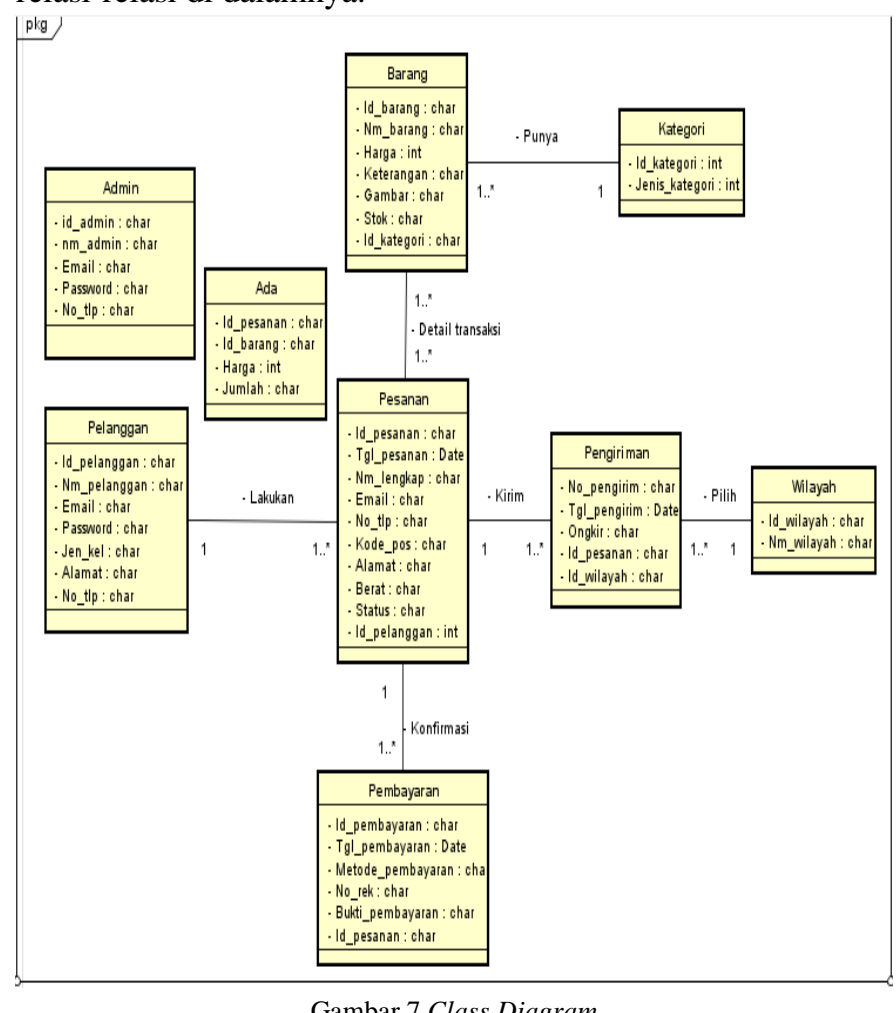

Gambar 7.Class Diagram

Gambar 7 adalah Class Diagram dari hasil analisa kebutuhan yang terdiri dari 9 class. 


\section{HASIL DAN PEMBAHASAN}

A. Tampilan Layar

1) Halaman Dashboard

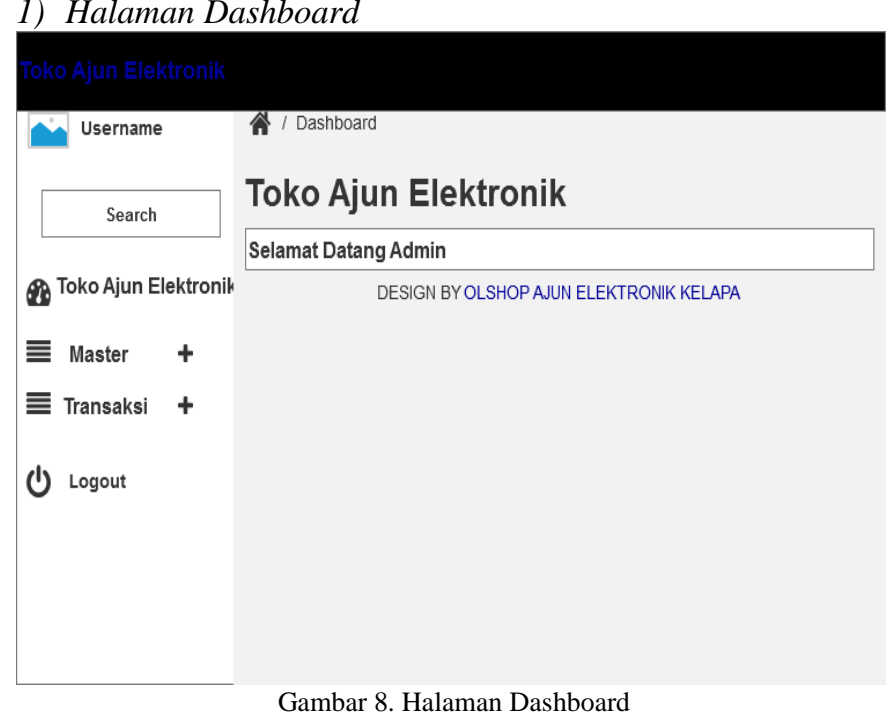

Gambar 8 menunjukkan tampilan menu dashboard dimana fungsinya menampilkan menu seperti login, master dan transaksi.

\section{2) Halaman Detail Produk}
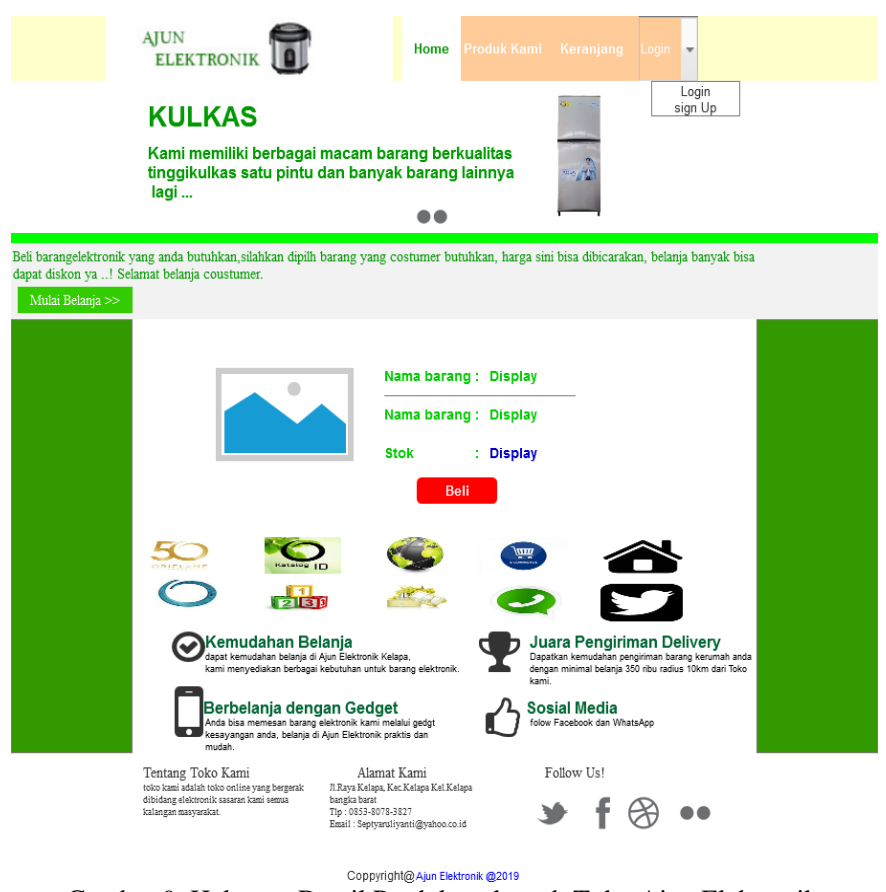

Gambar 9. Halaman Detail Produk pada web Toko Ajun Elektronika

Gambar 9 menunjukkan tampilan produk yang di jual yang berisi spesifikasi produk.

\section{3) Halaman Keranjang Pelanggan}

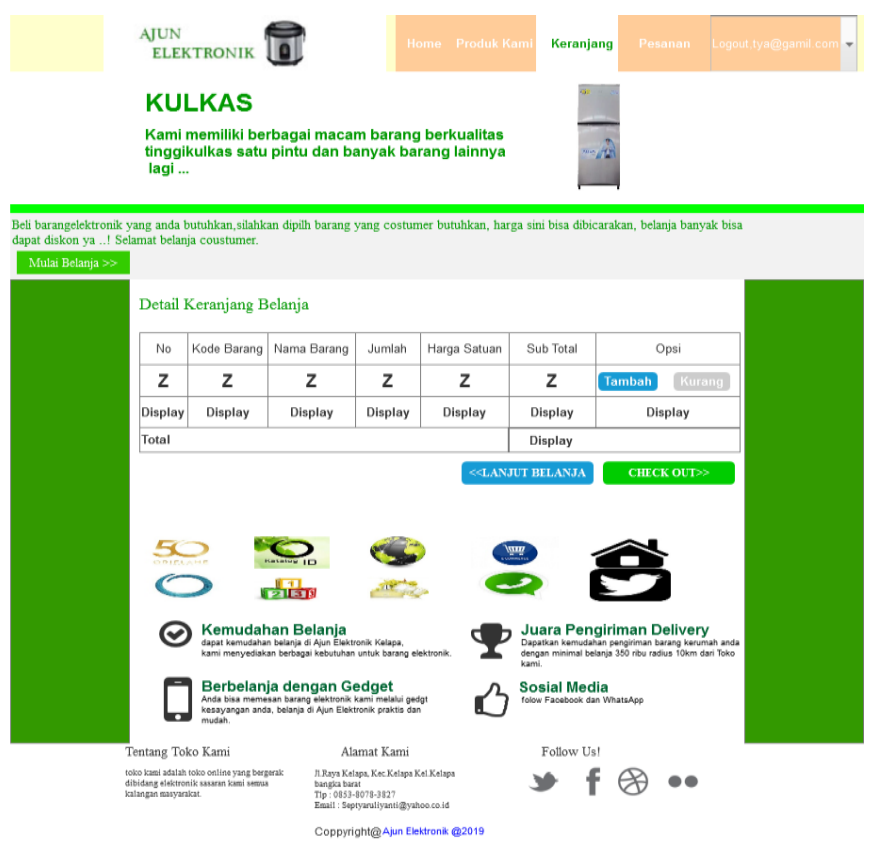

Gambar 10. Halaman Keranjang Pelanggan pada web Toko Ajun Elektronika

Gambar 10 menunjukkan tampilan transaksi pemesanan yang menampilkan detail keranjang pada web berisikan produk yang dipilih oleh pelanggan.

\section{4) Halaman Detail Pesanan Pelanggan}
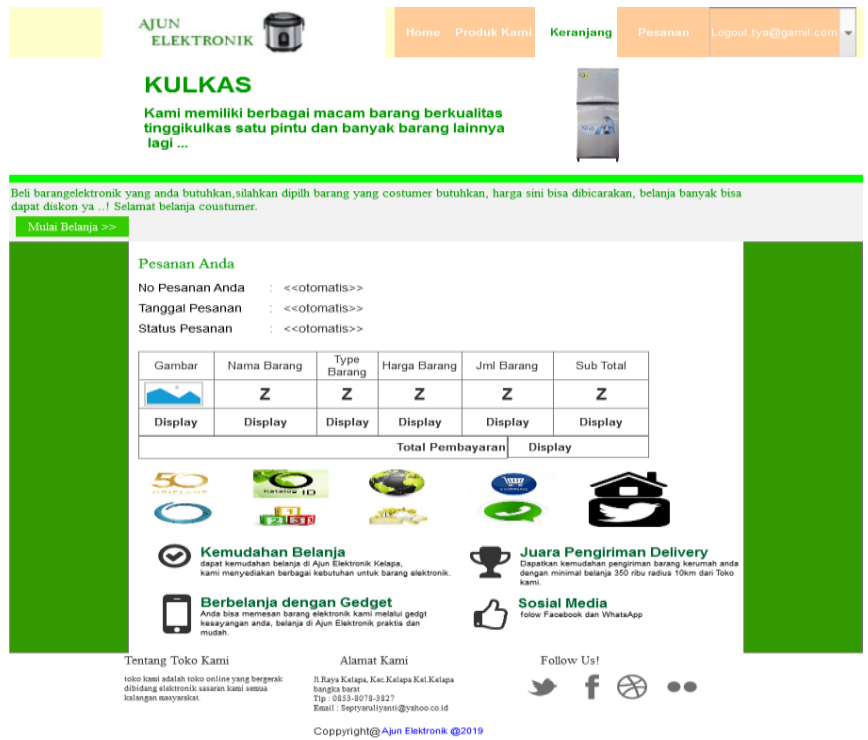

Gambar 11. Halaman Detail Pesanan Pelanggan pada web Toko Ajun Elektronika

Gambar 11 menunjukkan tampilan transaksi pemesanan yang menampilkan detail produk yang dipesan oleh pelanggan.

5) Halaman Pembayaran Pelanggan 


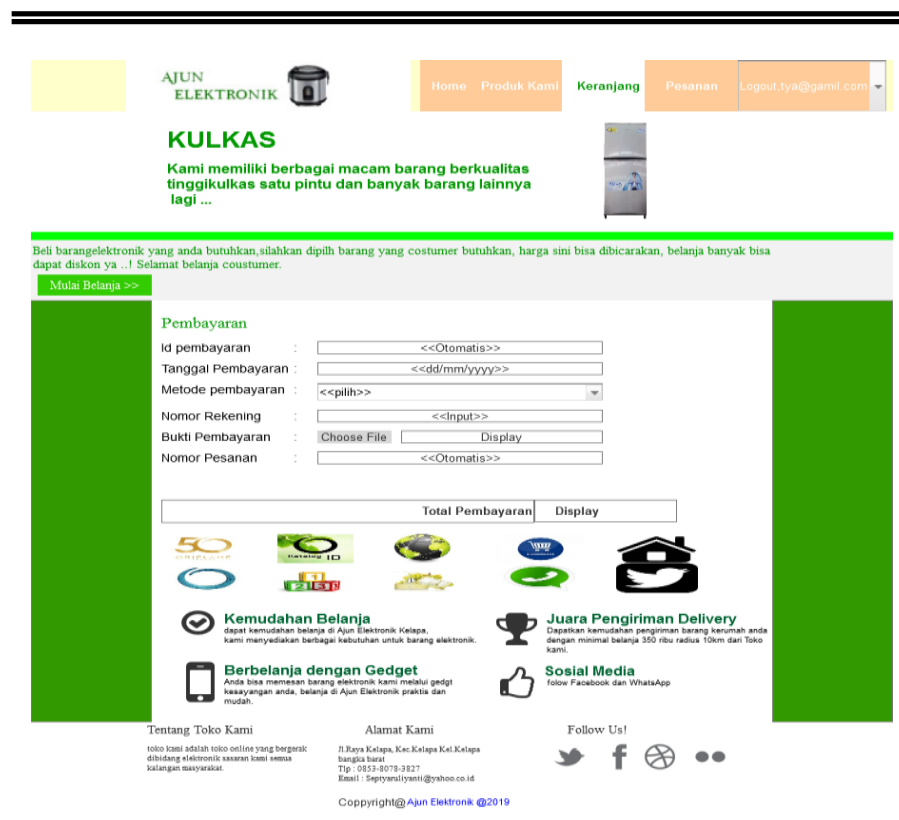

Gambar 12. Halaman Pembayaran Pelanggan pada web Toko Ajun Elektronika

Gambar 12 menunjukkan tampilan pembayaran pelanggan yang menampilkan tanggal pembayaran, jumlah bayar dan bukti pembayaran berdasarkan nomor pesanan.

\section{6) Halaman Pesanan Diterima Pelanggan}
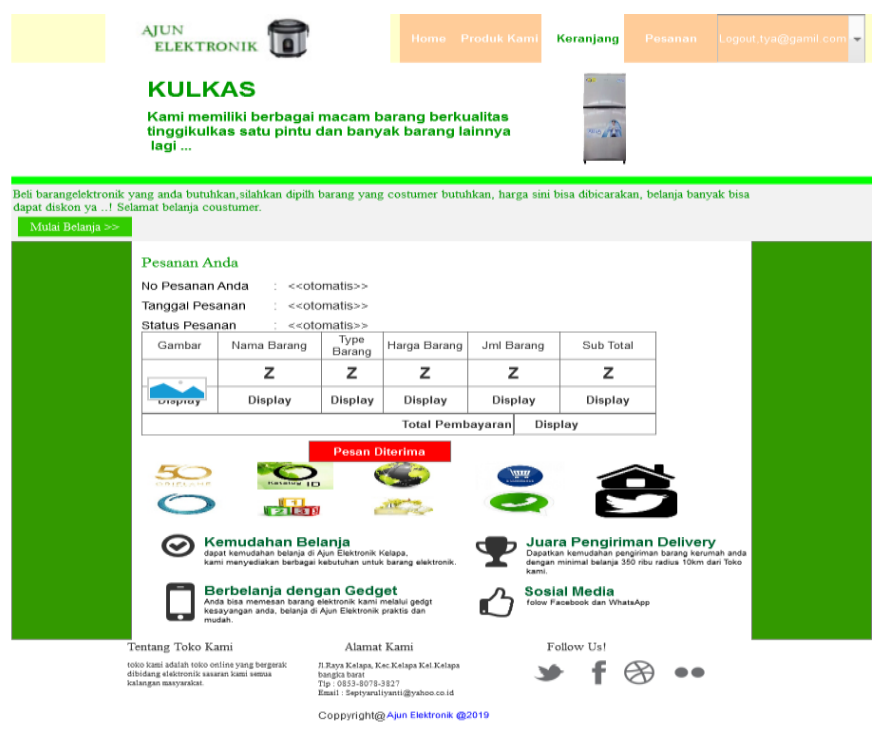

Gambar 13. Halaman Pesanan Diterima Pelanggan pada web Toko Ajun Elektronika

Gambar 13 menunjukkan tampilan pesanan pelanggan yang menampilkan data pesanan diterima oleh pelanggan.

\section{B. Pengujian Sistem}

Pada tahap ini dilakukan uji coba aplikasi menggunakan metode black box testing yaitu dengan menggunakan metode pengujian logika program. Hasil pengujian dari sistem ini dapat dilihat pada tabel berikut :

TABEL 1. Hasil Pengujian

\begin{tabular}{|l|l|l|c|}
\hline No & \multicolumn{1}{|c|}{ Kategori Tes } & \multicolumn{1}{|c|}{ Hasil yang diharapkan } & Hasil \\
\hline 1. & $\begin{array}{l}\text { Tampil detail } \\
\text { produk }\end{array}$ & $\begin{array}{l}\text { Dapat menampilkan detail } \\
\text { spesifikasi produk yang dipilih } \\
\text { pelanggan dari database }\end{array}$ & OK \\
\hline 2. & $\begin{array}{l}\text { Detail keranjang } \\
\text { pelanggan }\end{array}$ & $\begin{array}{l}\text { Dapat menampilkan detail } \\
\text { keranjang pelanggan }\end{array}$ & OK \\
\hline 3. & Simpan Pesanan & $\begin{array}{l}\text { Dapat menambah data pesanan } \\
\text { pelanggan kedalam database }\end{array}$ & OK \\
\hline 4. & $\begin{array}{l}\text { Detail pesanan } \\
\text { pelanggan }\end{array}$ & $\begin{array}{l}\text { Dapat menampilkan detail } \\
\text { pesanan pelanggan dari } \\
\text { database }\end{array}$ & OK \\
\hline 5. & $\begin{array}{l}\text { Simpan pembayaran } \\
\text { pelanggan }\end{array}$ & $\begin{array}{l}\text { Dapat menyimpan data dan } \\
\text { bukti pembayaran pelanggan }\end{array}$ & OK \\
\hline 6. & $\begin{array}{l}\text { Pesanan diterima } \\
\text { pelanggan }\end{array}$ & $\begin{array}{l}\text { Dapat menampilkan status } \\
\text { pesanan diterima oleh } \\
\text { pelanggan }\end{array}$ & OK \\
\hline
\end{tabular}

Hasil penelitian menghasilkan sistem yang dapat memberikan kemudahan mengenalkan produk di Ajun elektronik dan menjual semua produk elektronik kebutuhan rumah tangga, Dengan adanya wevsite e-commerce yang mampu memberikan informasi mengenai produk kepada pelanggan dengan cepat melalui teknologi jaringan internet. Software pendukung aplikasi ini dengan menggunakan framework. Prototype E-commerce ini telah diuji dari segi verifikasi, validasi, dan pengujian prototype. Dari hasil pengujian tersebut, dapat disimpulkan bahwa Prototype Ecommerce ini telah berhasil dan sesuai dengan tujuan perancangan sistem.

\section{PENUTUP}

Dengan adanya website ini maka toko dapat memperluas pemasaran, Konsumen menjadi lebih mudah mendapatkan informasitentang barang tanpa harus datang ke Toko Ajun Elektronik dan dengan adanya sistem penjualan online ( $e$ commerce) maka toko dapat memudahkan proses transaksi yang selama ini sifatkan konvensional menjadi modern dengan terjadinya transaksi online. Dan kemudian dengan adanya website ini dapat mempermudah dalam membuat laporan penjualan yang sebelumnya masih bersifat manual. Adapun saran dari penelitian ini Perlu adanya pengembangan pada desain tampilan agar lebih menarik sehingga dapat lebih banyak menarik minat pelanggan.

\section{DAFTAR PUSTAKA}

[1] Fitri Purwaningtias, April 2018, E-Commerce Penjualan Berbasis Metode OOAD (Studi Kasus : Pt Musi Utama Bercahaya Palembang), Volxv,Issn:0216-9436,

[2] Ambo Aco, Andi Hutami Endang, 2017, Analisis Bisnis E-Commerce Pada Mahasiswa Universitas Islam Negeri Alauddin Makassar, No. 1, Vol 2.

[3] Shabur Miftah Maulana, Heru Susilo, Riyadi, 2015, Implementasi ECommerce Sebagai Media Penjualan Online (Studi Kasus Pada Toko Pastbrik Kota Malang), No. 1, Vol 29.

[4] Noorhansyah, Dan Adi Pratomo, Mei 2016, Penerapan Model Customer Relationship Managementpada Metodologi Fast (Studi 
Kasus:Pengembangan Portal Akademik Jurusan Administrasi Bisnis Politeknik Negeri Banjarmasin,No.2,Vol1,25-32.

[5] Anggara Aji Saputra, 2015, Metode Pengembangan FAST

(Freamwork For Application Of Systems Technology),

[6] Sarwindah,Januari 2019, Pemanfaatan Aplikasi Dekstop Dalam Proses Sistem Pengiriman Furnicture Pada A \& N Interior, Jurnal SISTEMASI, Volume 8, Nomor 1 Januari 2019: $137-144$

[7] Widianto, Didik 2015, Sistem Penjualan Elektronik Batik Pacitan Berbasis Website, Indonesian Journal on Networking and Secutiry, Vol 4 No 1, Universitas Surakarta, Solo

[8] Amplitude, "E-Commerce In Indonesia," 2018.

[9] Priyo Sutopo, Dedi Cahyadi, dan Zainal Arifin, 2016, Jurnal Informatika Mulawarman, Sistem Informasi Eksekutif Sebaran Penjualan Kendaraan Bermotor Roda 2 Di Kalimantan Timur Berbasis Web, No. 1, Vol 11,

[10] Fitri Purwaningtias, April 2018, E-Commerce Penjualan Berbasis Metode Ooad (Studi Kasus : PT Musi Utama Bercahaya Palembang), Vol XV,Issn:0216-9436,

[11] Sarwindah September 2018, Sistem Pendaftaran Siswa Baru Pada SMP N 1 Kelapa Berbasis Web Menggunakan Model UML, Jurnal Sisfokom, Volume 7, Nomor 2 September 2018 : 110-115

[12] Shabur Miftah Maulana, Heru Susilo, Riyadi, Desember 2015, Implementasi E-Commerce Sebagai Media Penjualan Online(Studi Kasus Pada Toko Pastbrik Kota Malang) Jurnal Administrasi Bisnis (JAB), Vol. 29 No. 1 Desember2015

[13] Sheila Fitria Nurjanah, Rini Rahayu Kurniati, Daris Zunaida, Agustus 2019 Pengaruh E-Commerce Terhadap Keputusan Pembelian Pada Belanja Online Shopee (Studi Pada Konsumen Belanja Online Mahasiswa Universitas Islam Malang), JurnalJIAGABI, Vol. 8, No. 3, 1 Agustus 2019, hal. 154-162

[14] Hani Atun Mumtahana, Sekreningsih Nita, Adzinta Winerawan Tito, Juni 2017 Pemanfaatan Web E-Commerce Untuk Meningkatkan Strategi Pemasaran, Khazanah Informatika, Vol.3, No.1 Juni 2017

[15] Sandi Kosasi, 2015 Perancangan Sistem E-Commerce Untuk Memperluas Pasar Produk Oleh-Oleh Khas Pontianak, SNASTIA 2015.

[16] SutriHandayani,Agustus2018,Perancangansysteminformasipenjualanbe rbasis E-Commercestudi Kasus Toko Kun Jakarta, Junal ILKOM, Vol.10, No.2 Agustus 2018. 